Neima, S. G., D. J. Hamilton, C. L. Gratto-Trevor, and J. Paquet. 2020. Intra- and interannual regional fidelity of Semipalmated Sandpipers (Calidris pusilla) during migratory stopover in the upper Bay of Fundy, Canada. Avian Conservation and Ecology 15(1):14. https://doi.org/10.5751/ ACE-01561-150114

Copyright (C) 2020 by the author(s). Published here under license by the Resilience Alliance.

Research Paper

\title{
Intra- and interannual regional fidelity of Semipalmated Sandpipers (Calidris pusilla) during migratory stopover in the upper Bay of Fundy, Canada
}

\author{
Sarah G. Neima ${ }^{1}$, Diana J. Hamilton ${ }^{1}$, Cheri L. Gratto-Trevor ${ }^{2}$ and Julie Paquet $^{3}$ \\ ${ }^{1}$ Department of Biology, Mount Allison University, Sackville, New Brunswick, Canada, ${ }^{2}$ Prairie and Northern Wildlife Research \\ Centre, Science and Technology Branch, Environment and Climate Change Canada, Saskatoon, Saskatchewan, Canada, ${ }^{3}$ Canadian \\ Wildlife Service, Environment and Climate Change Canada, Sackville, New Brunswick, Canada
}

\begin{abstract}
The Bay of Fundy, Canada is a critical migratory stopover for Semipalmated Sandpipers (Calidris pusilla) during fall migration. Recent ecological changes combined with range-wide population declines indicate that a re-evaluation of habitat use and regional fidelity is required. The Bay of Fundy is divided into three regions, each of which contains multiple foraging and roost sites. In this study, we examined local movement and regional fidelity within and between years using radio-telemetry and field-readable markers. We deployed 194 radio-transmitters and 2295 field-readable flags on Semipalmated Sandpipers during migration in 2013-2014, and resighted these birds, along with additional birds flagged in 2012, between 2013 and 2016. Radio-tracked birds used on average 1.3 to 4.1 foraging and roost sites per day, with most making multiple daily movements, but only $2 \%$ made permanent moves between geographically distant regions within the bay during stopover. Additionally, $97 \%$ of birds returned to their original region in subsequent years. The use of multiple sites suggests Semipalmated Sandpipers are capable of adapting to dynamic conditions in the Bay of Fundy on a local scale, but the high regional fidelity suggests that their ability to adapt to changes occurring at a regional scale may be limited. Uncertainty about the capability of Semipalmated Sandpipers to flexibly move among different regions of the Bay of Fundy supports the need for conservation at both the site and regional level.
\end{abstract}

\section{Fidélité régionale intra- et interannuelle des Bécasseaux semipalmés (Calidris pusilla) aux haltes migratoires dans le fond de la baie de Fundy, Canada}

RÉSUMÉ. La baie de Fundy, au Canada, représente une halte essentielle pour les Bécasseaux semipalmés (Calidris pusilla) durant la migration automnale. Une réévaluation de l'utilisation de l'habitat et de la fidélité régionale est nécessaire en raison de changements écologiques récents couplés aux diminutions de population à grande échelle. La baie de Fundy se divise en trois régions, chacune comptant de nombreux sites d'alimentation et de repos. Nous avons examiné les déplacements locaux et la fidélité régionale des bécasseaux au cours d'une même année et entre les années, au moyen de la radiotélémétrie et de marqueurs lisibles à distance sur le terrain. Nous avons posé 194 émetteurs radio et 2295 marqueurs sur des Bécasseaux semipalmés durant les migrations de 2013 et 2014 , et avons réobservé ces oiseaux de 2013 à 2016, en plus d'autres oiseaux munis de marqueurs en 2012. Les oiseaux suivis par radio ont utilisé de 1,3 à 4,1 sites d'alimentation et de repos en moyenne par jour, la plupart se déplaçant plusieurs fois quotidiennement, tandis que $2 \%$ seulement se sont déplacés de façon permanente entre des régions distantes dans la baie en cours de halte. De plus, $97 \%$ des oiseaux sont retournés dans leur région d'origine dans les années subséquentes. Le fait que les Bécasseaux semipalmés utilisent de multiples sites donne à penser qu'ils sont capables de s'adapter aux conditions dynamiques de la baie de Fundy à l'échelle locale, mais leur fidélité régionale élevée laisse croire que leur capacité à s'adapter aux changements advenant à l'échelle régionale serait limitée. L'incertitude quant à la capacité des Bécasseaux semipalmés de se déplacer facilement entre les différentes régions de la baie de Fundy confirme le besoin en matière de conservation aux échelles du site et de la région.

Key Words: Bay of Fundy; migratory stopover; Motus Wildlife Tracking System; radio telemetry; regional fidelity; Semipalmated Sandpipers (Calidris pusilla)

\section{INTRODUCTION}

During migration, many shorebirds rely on a thin band of tidal habitat between vast stretches of land and ocean. Within this band, only limited stretches combine both the food resources and protection from disturbance necessary for successful migration, driving birds to concentrate at a few high-quality staging areas. Migrants that use only one or two staging areas to fuel long distance, nonstop flights are especially dependent on abundant and predictable food resources (Baker et al. 2004, Mizrahi et al. 2012, Galbraith et al. 2014). Selection of roost and foraging sites within staging areas can be influenced by factors such as prey density (Hicklin and Smith 1984, Goss-Custard et al. 1991), perceived predation risk and site safety (Sitters et al. 2001, Ydenberg et al. 2002, Sprague et al. 2008), individual fuel loads (van Gils and Piersma 1999), bill and gut morphologies 
(Sutherland et al. 2000), and physical characteristics of the site (Danufsky and Colwell 2003). Fidelity to particular sites can confer benefits both within and between years through past knowledge of food resources, location of safe roost sites, and knowledge of predation risk (Ydenberg et al. 2004, Buchanan et al. 2012). Conversely, flexible site use may allow individuals to adapt to changing conditions and disturbances (Colwell et al. 2003, Sitters et al. 2001, Ydenberg et al. 2004). Interannual fidelity is common in shorebirds on the wintering (e.g., Harrington et al. 1988, Leyrer et al. 2006) and breeding grounds (e.g., Haig and Oring 1988, Handel and Gill 2000) but is less well understood during migration. Some shorebirds exhibit high fidelity to particular sites (Farmer and Parent 1997, Butler et al. 2002, Buchanan et al. 2012), whereas others roam widely across staging areas (van Gils and Piersma 1999, Colwell et al. 2003).

The Bay of Fundy, Canada, is one of the largest high-quality staging areas for Semipalmated Sandpipers (Calidris pusilla) using the Atlantic Flyway during fall migration and has been designated as a Western Hemisphere Shorebird Reserve Network (WHSRN) landscape of hemispheric importance. The Bay experiences the world's highest tides (O'Reilly et al. 2003) and during each tidal cycle, 35,000 ha of invertebrate-rich mudflats are exposed (Hicklin 1987). It consists of two separate arms, one of which can further be divided into two subsections, all containing multiple roosting and foraging sites (Fig. 1). We will refer to the Bay of Fundy as a whole as the "staging area," the three subsections as "regions," and individual foraging mudflats or roost beaches as "sites." Semipalmated Sandpipers are small Nearctic shorebirds that breed across the Canadian Arctic and Alaska. A significant portion of the central and eastern breeding population relies on the Bay of Fundy to fuel a 3-day, $4000 \mathrm{~km}$ transoceanic flight to wintering grounds along the northern and central coasts of South America (Hicklin and Smith 1979, GrattoTrevor et al. 2012a). It has been estimated that the bay hosts over $50 \%$ of the global population of Semipalmated Sandpipers during migration (Mawhinney et al. 1993), and that this species constitutes up to $95 \%$ of the migratory shorebird population in the Bay of Fundy during the fall (Hicklin 1987). Population declines have been observed in Semipalmated Sandpipers throughout their wintering range (Morrison et al. 2012) and during migration (Gratto-Trevor et al. 2012b), although evidence from the Arctic is mixed (Smith et al. 2012). It was previously thought that Semipalmated Sandpipers were highly faithful to particular roosting and foraging sites within the Bay of Fundy, with only $14 \%$ of birds marked at one roost observed at other roosts less than $20 \mathrm{~km}$ away (Hicklin 1987). However, more recent studies have indicated that individuals may move up to $20 \mathrm{~km}$ daily during their stopover within a single season (Sprague et al. 2008, White 2013) and may be using more nontraditional roost sites (MacKinnon et al. 2008).

To understand movement strategies employed by Semipalmated Sandpipers migrating through the Bay of Fundy, we investigated the extent of intra- and interannual fidelity as well as changes in movement frequency throughout the stopover in 2013-2016. A secondary goal was to characterize movements throughout the stopover period. Such knowledge is important because conditions for Semipalmated Sandpipers in this region have changed. Hicklin (1987) hypothesized that individual sandpipers use a highly restricted set of sites, but that may no longer be the case. We now know that the prey base and diet vary between the arms of the bay (Quinn and Hamilton 2012, Gerwing et al. 2016), with increases in some prey and declines in others relative to values in the 1970s and 1980s. Peregrine Falcons (Falco peregrinus) are now much more prevalent and are known to affect shorebird movement and habitat use (Dekker et al. 2011, Hope et al. 2020). Semipalmated Sandpipers are migrating through the region later (Bliss et al. 2019), and the population of sandpipers using the bay is now estimated to be less than half of what it was in the 1970s (Neima 2017). We revisited Hicklin's (1987) hypothesis and predicted that birds now are likely to require increased flexibility in movement and habitat use relative to what was previously observed. We also determined for the first time the extent to which individuals return to the same regions of the Bay of Fundy in subsequent years. This raises questions about long term population-level effects of site selection, necessitating a clearer understanding of habitat use and site fidelity within the bay.

Fig. 1. Map of the upper Bay of Fundy showing the three regions of the bay (Chignecto Bay, Cobequid Bay, and Minas Basin), catch locations (black stars), and receiver locations (light gray circles; details provided in Appendix 2). Important foraging sites are shaded yellow, roost sites are blue, and sites that support both roosting and foraging are shaded magenta. Dark gray and white coloration represents water and land area, respectively.

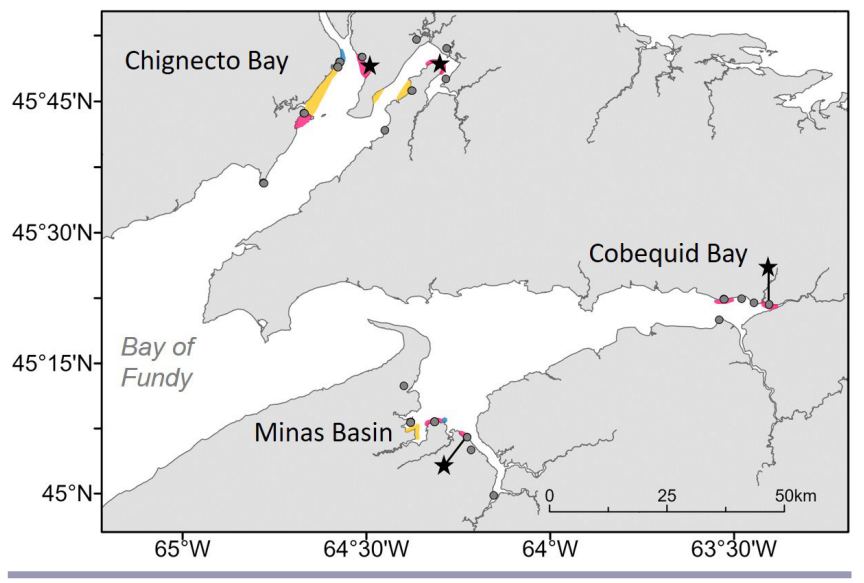

\section{METHODS}

\section{Capture methods and markers}

We captured Semipalmated Sandpipers in three regions within the Bay of Fundy throughout August 2013 and 2014: Chignecto Bay in New Brunswick and northern Nova Scotia, Cobequid Bay in central Nova Scotia, and Minas Basin in southwestern Nova Scotia (Fig. 1). Capture took place during high tide, using mist nets in Cobequid Bay and one Chignecto site (Minudie) and a Fundy pull-trap (Hicklin et al. 1989) at the other Chignecto site (Johnson's Mills) and in the Minas Basin. Details of catches can be found in Appendix 1. All birds captured were fitted with an individually numbered metal band on their lower right leg (for lifelong identification) and a yellow color band on their upper left leg (to identify them as part of our project). Birds were given an additional color band on their upper right leg to identify in which 
arm of the Bay they were captured (Chignecto Bay vs. Minas Basin). Most birds were also fitted with a field-readable white flag with a black three-digit alpha-numeric code on the upper left leg, for individual identification in the field. These flags allowed us to examine regional fidelity for birds returning in subsequent years.

To track movements during the stopover period, we deployed a total of 194 individually coded 0.35 -g Lotek radio-transmitters (NTQB-2, Lotek Wireless Inc., Newmarket, Ontario): 89 in 2013 and 105 in 2014 (see Appendix 1 for details). All tagged birds were adults (after hatch year). To maximize tracking time during the period that birds were present in the Bay of Fundy, light birds were selected to receive transmitters because their low mass suggested that they were recent arrivals in the region. Ninety-one percent of radio-tagged birds were lighter than $30 \mathrm{~g}$ at capture (maximum $=33.6 \mathrm{~g}$ ). Transmitters were glued to clipped contour feathers on the back just above the uropygial gland, as in Sprague et al. (2008). This attachment method allows for loss of transmitters when birds next molt. All transmitters were on a frequency of $166.380 \mathrm{MHz}$, with a burst rate of 5.9 to 6.1 seconds and an expected battery life of 38 days. Prior to this study, the maximum duration of stay detected for a Semipalmated Sandpiper in the Bay of Fundy was 28 days (White 2013), so these expected battery life estimates are sufficient to ensure function throughout the stopover period.

\section{Radio-tracking and resighting}

To monitor the movements of our radio-tagged birds, we used an array of stationary receiver towers (Fig. 1, with details provided in Appendix 2), now part of the Motus Wildlife Tracking System (Taylor et al. 2017), supplemented by mobile ground and aerial tracking. Stationary receivers were placed strategically to cover the maximum amount of potential habitat, as well as possible flyways in and out of the bay. In 2013, this array consisted of 15 receivers, with 4 additional receivers deployed in 2014 (Fig. 1; Appendix 2). Stationary receivers were either a Lotek DL model (Lotek Wireless Inc., Newmarket, Ontario) or a Sensorgnome (Taylor et al. 2017) and were connected to one to three, nineelement Yagi antennas with the elements oriented horizontally. Antennas were attached to a nine-meter tower or to an existing structure and were oriented to direct the detection beam over the relevant mudflat, roost site, or body of water (Fig. 1; Appendix 2). The units logged tag detections, time of detection, and GPS location of the tower for the duration of the study. Range of individual receivers varies substantially with position of birds relative to antennas and antenna elevation, but optimally is 15-20 $\mathrm{km}$ when unobstructed (Taylor et al. 2017). However, when birds are on the ground, as they would be during feeding or roosting, detection range is often $1-2 \mathrm{~km}$ or less.

Mobile ground tracking was performed opportunistically at known foraging and roost sites (Fig. 1) throughout the Bay of Fundy using a Lotek SRX600 receiver (Lotek Wireless Inc., Newmarket, Ontario) and a handheld three- or five-element Yagi antenna. Aerial tracking was performed in a Cessna 172 fixedwing aircraft fitted with two H-style antennae mounted on the wing struts connected to a Lotek SRX600 receiver. Surveys commenced immediately following deployment of the first transmitters and were flown every one to four days, depending on weather conditions, until no birds were detected. We flew 17 surveys in 2013 and 11 in 2014. Flights were conducted at high and low tide to detect birds at both foraging and roost sites. Each survey was conducted at an altitude of roughly $90 \mathrm{~m}$ and covered the coastline of the study area in approximately 4 hours. Interference from newly installed plane equipment in 2014 limited detection sensitivity, but any detections obtained were retained. The stationary array was sufficient for tracking birds throughout their stopover and detecting movements between primary mudflats and roost sites (Fig. 1), allowing comparisons between years. The supplemental mobile tracking was used mainly to obtain a more detailed picture of the full extent of sandpiper habitat use in the upper Bay of Fundy (Figs. 2 and 3).

To assess regional and site fidelity both within and between years, we collected resighting data from 2013 to 2016 on 2295 birds flagged during our study, as well 726 birds flagged during a 2012 pilot study (White 2013), and 9 birds flagged elsewhere but resighted in at least 2 years in the Bay of Fundy. For those birds, we treated the location of first sighting as equivalent to the banding location. Resighting efforts consisted of one to two observers with spotting scopes surveying flocks at roost sites, usually for a minimum of two hours before and two hours after high tide. All marked individuals were recorded, including color band combinations and flag colors and codes, along with location, date, and time. We also received resighting information from local birders in the form of photos, which we included in our analysis. Resighting in 2013 and 2014 was performed opportunistically, when time was available outside of catching efforts, for a total of approximately 44 and 59 person-hours, respectively. Resighting was the main priority in 2015 and 2016, totaling 231 and 368 person-hours, respectively, and was organized to cover sites as equally as possible and to minimize observer bias by regularly moving observers between sites. Resighting in Cobequid Bay was ineffective because vantage points were limited. We attempted limited resighting there in 2015 (20 person-hours) but detected no flagged birds. Because of this, we did not resight there in 2016.

\section{Data analysis}

We used radio-telemetry data to investigate within-year movements among regions of the bay (intra-annual regional fidelity) and movements within regions. For all analyses of the radio-telemetry data, we excluded any data from birds that were tracked for less than five days (i.e., last detection was less than five days after tagging; $\mathrm{N}_{2013}=8, \mathrm{~N}_{2014}=13$ ). Five days was chosen as a cutoff because these individuals were clear outliers when compared to the rest of the population with respect to duration of stay (Neima 2017). Most of these birds (6 of 8 in 2013 and 8 of 13 in 2014) were tracked for a day or less, and in these cases, it is likely that the transmitters malfunctioned or were lost. We also excluded data from birds that were detected during less than $30 \%$ of their total stopover (i.e., had large gaps in their detection history) because they could have used resources outside the Bay of Fundy during that time $\left(\mathrm{N}_{2013}=3, \mathrm{~N}_{2014}=0\right)$. The remaining birds $\left(\mathrm{N}_{2013}=78, \mathrm{~N}_{2014}=82\right)$ were included in analyses of tracking data. When examining movements during stopover, we excluded the last 24 hours of detections for each individual to avoid confusing local movements and departure movements, which take birds outside the Bay of Fundy. We quantified the extent of within-region movement based on radio-tracking from stationary receivers. We defined a move as a change in detections from one tower to another, excluding simultaneous or alternating 
Fig. 2. Detections of radio-tagged individuals during stopover in the upper Bay of Fundy in 2013. (A) Individuals tagged in the different regions are denoted by different colors; red denotes Chignecto Bay, blue Minas Basin, and yellow Cobequid Bay. (B-D) Detailed movements within each region of the bay. In all maps, thickness of lines represents proportion of total number of movements between sites (including repeated movements by individuals). Plotted data include detections by stationary receivers and aerial tracking. Additional detail on movements is provided in Appendix 3, Figure A3.1.
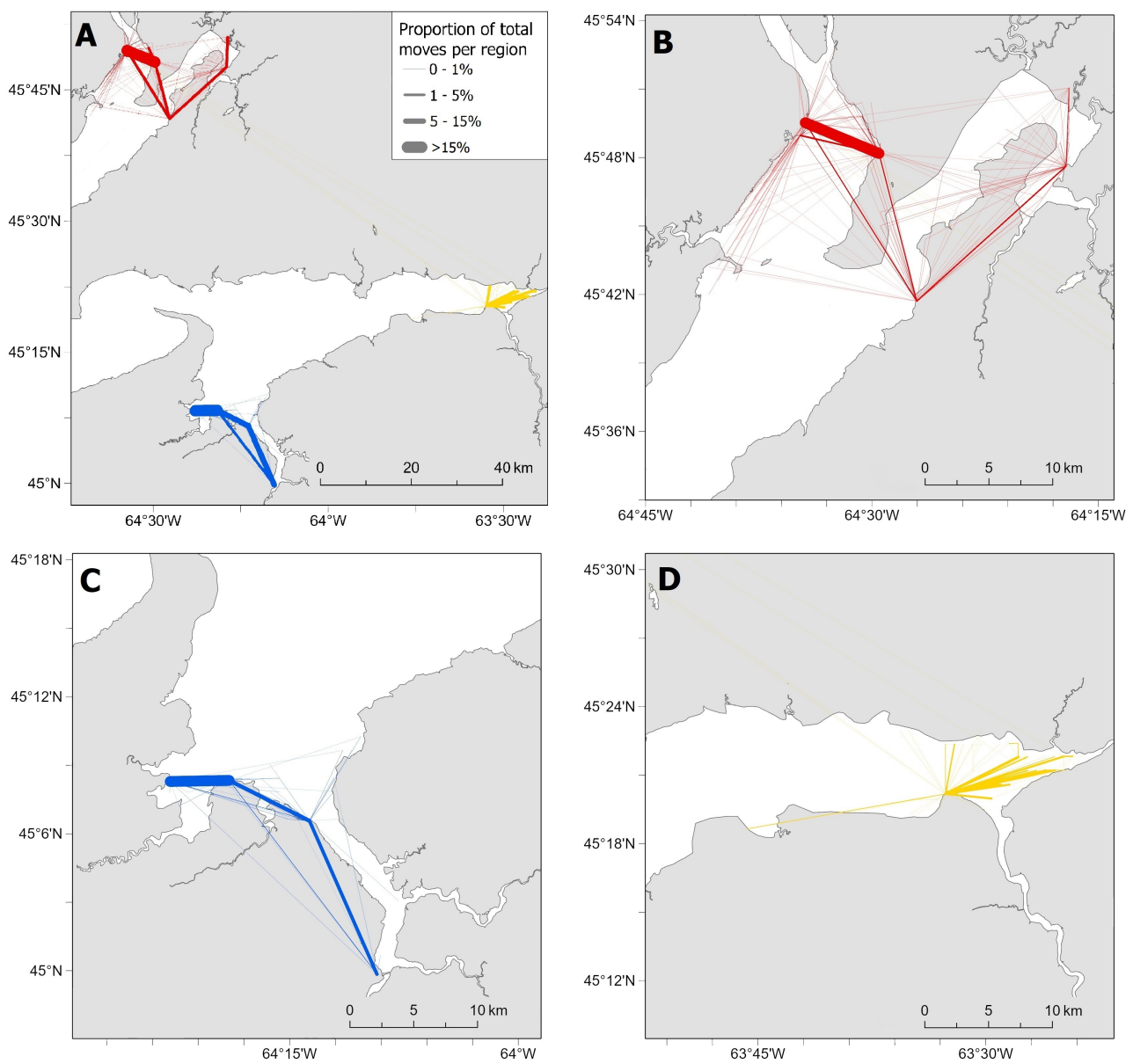

detections that could result from birds flying in the detection cone of more than one tower simultaneously (i.e., where tower detection cones overlap). We also excluded changes that involved birds moving from a roosting site to the closest foraging site, or the reverse. This was primarily an issue with two towers at Hopewell Cape, New Brunswick, one of which was oriented toward a roost and the other toward a mudflat foraging site. In all cases, we required three consecutive hits to filter out false detections (Crewe et al. 2019). We assessed variation among regions and years in mean number of movements per bird per day using a generalized linear mixed effects model ( $\mathrm{R}$ package lme4, Bates et al. 2015) with number of movements per bird per day as the dependent variable, region and year as fixed factors, and bird as a random factor. We modeled data using a negative binomial distribution to accommodate our non-normal count data and to account for overdispersion. We could not include Cobequid Bay in this analysis because we had only one tower there in 2013, and therefore movements were not detectable. We then expanded the models to investigate whether time in an individual's stopover period may influence movement (e.g., more movement earlier in an individual's stopover). In this case, we analyzed the data separately for the two years to facilitate inclusion of Cobequid Bay in 2014 and added a continuous predictor of days post tagging for each bird. All analyses were conducted using $\mathrm{R}$ version 3.5.2 on an R Studio platform.

We assessed the extent to which birds used the same region of the bay year after year (interannual regional fidelity) by examining the proportion of flagged individuals resighted in subsequent years in the same region of the Bay of Fundy (i.e., Chignecto or Minas) in which they were tagged. We included all resights in which the observer was at least $90 \%$ certain of all digits in the code (e.g., code ABC, certainty 100/100/90 or 90/90/90, but not $100 / 100 / 80$ ). When individuals were seen in multiple years they were counted only once, either as returning to their original region 
Fig. 3. Detections of radio-tagged individuals during stopover in the upper Bay of Fundy in 2014. (A) Individuals tagged in the different regions are denoted by different colors; red denotes Chignecto Bay, blue Minas Basin, and yellow Cobequid Bay. (B-D) Detailed movements within each region of the bay. In all maps, thickness of lines represents proportion of total number of movements between sites (including repeated movements by individuals). Plotted data include detections by stationary receivers and aerial tracking, though aerial tracking was very limited in 2014. Additional detail on movements is provided in Appendix 3, Figure A3.2.
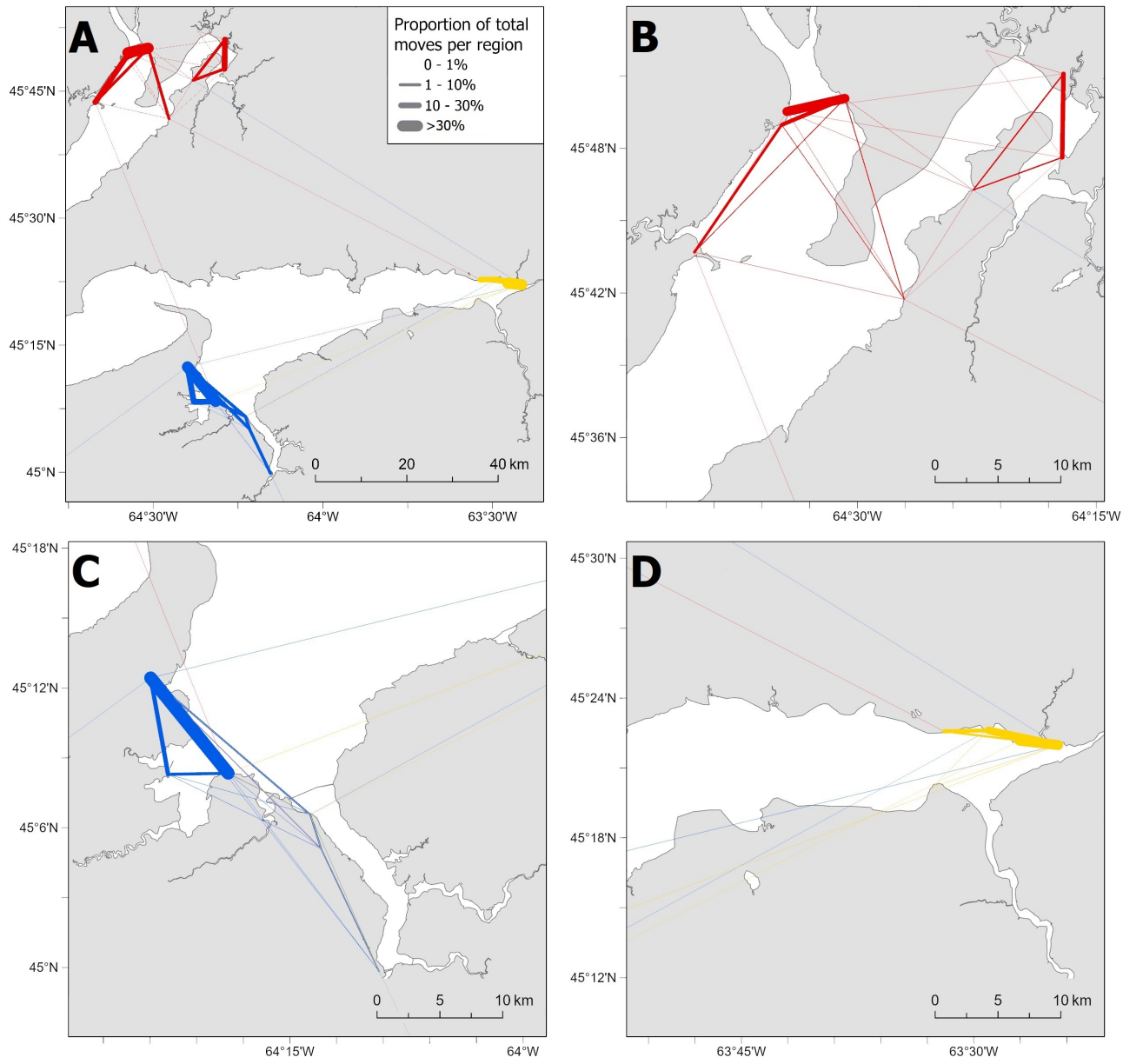

("returning") if they did so every year they were resighted, or as not returning ("switching") if they were ever resighted outside the region in which they were originally detected. It is possible that we may be overestimating regional fidelity because most birds were only seen in two years (banding year plus one subsequent year) and just once per year, and the likelihood of detecting a switch among regions might go up with multiple years of resighting and telemetry data. To assess this, we also separately examined data from birds that were seen in at least three years.

\section{RESULTS}

\section{Within-year movement patterns}

Only eight radio-tracked individuals $(5 \%$ of the tagged population) were ever detected outside the region of the bay in which they were tagged. Half of this movement (4 individuals) consisted of temporary moves lasting less than 48 hours, after which they returned to their original region. The other four individuals, all tagged in 2014, left their region and resided elsewhere until departure. One bird moved from Chignecto Bay to Cobequid Bay, one moved from Chignecto Bay to Minas Basin, one moved from Cobequid Bay to Minas Basin, and one bird moved from Minas Basin to Cobequid Bay, then to Chignecto Bay where it remained until departure (Appendix 3). Resighting data provided a similar picture with respect to intra-annual regional fidelity; we saw 189 flagged birds more than once within the same year, and none of them switched regions.

Conversely, individual birds moved frequently within each region of the bay throughout the stopover period in both years (Figs. 2 and 3). Distances between catch locations and other mudflats and roost sites within a region ranged from approximately $1.1 \mathrm{~km}$ to $33.1 \mathrm{~km}$ (Fig. 1). Radio-tracked birds made an average of 1.3 to 
Table 1. Percent of total moves occurring between pairs of receivers within regions and years, as determined from radio-tracking data obtained from stationary receivers. Distance between receivers is provided. Each subsection is arranged from closest to most distant receivers. Only moves that comprised at least $2 \%$ of total moves are presented. Most common moves are highlighted in bold.

\begin{tabular}{|c|c|c|c|c|}
\hline Year & Capture location & Movement & $\begin{array}{c}\% \text { of total } \\
\text { moves }\end{array}$ & $\begin{array}{l}\text { distance between } \\
\text { receivers }(\mathrm{km})\end{array}$ \\
\hline \multirow[t]{9}{*}{2013} & Chignecto Bay & Johnson's Mills - Hopewell Roost & 64.4 & 4.9 \\
\hline & & Johnson's Mills - Hopewell Flats & 8.9 & 5.7 \\
\hline & & Amherst Point - Beaubassin & 4.5 & 6.4 \\
\hline & & Johnson’s Mills - Joggins & 6.4 & 16.3 \\
\hline & & Amherst Point - Joggins & 8.7 & 16.9 \\
\hline & & Hopewell Roost - Joggins & 3.1 & 17.4 \\
\hline & Minas Basin & Evangeline Beach - Porter's Point & 56.1 & 5.1 \\
\hline & & Avonport - Evangeline Beach & 22.1 & 7.7 \\
\hline & & Avonport - Windsor & 16.9 & 13.7 \\
\hline \multirow[t]{16}{*}{2014} & Chignecto Bay & Johnson's Mills - Hopewell Roost & 33.5 & 4.9 \\
\hline & & Johnson's Mills - Hopewell Flats & 14.2 & 5.7 \\
\hline & & Amherst Point - Beaubassin & 15.5 & 6.4 \\
\hline & & Mill Creek - Beaubassin & 4.8 & 11.6 \\
\hline & & Hopewell Flats - Mary's Point & 9.3 & 12.0 \\
\hline & Cobequid Bay & Cobequid 2 - Cobequid 3 & 5.7 & 2.8 \\
\hline & & Fort Belcher - Cobequid 3 & 38.0 & 3.3 \\
\hline & & Cobequid 1 - Cobequid 2 & 14.7 & 3.8 \\
\hline & & Fort Belcher - Cobequid 2 & 29.3 & 6.0 \\
\hline & & Fort Belcher - Cobequid 1 & 7.4 & 9.7 \\
\hline & Minas Basin & Avonport - Lockhart & 6.1 & 2.9 \\
\hline & & Evangeline Beach - Porter's Point & 10.6 & 5.1 \\
\hline & & Porter's Point - Lookoff & 15.8 & 7.8 \\
\hline & & Evangeline Beach - Lookoff & 48.8 & 10.0 \\
\hline & & Lockhart - Windsor & 2.2 & 10.7 \\
\hline & & Avonport - Lookoff & 5.7 & 17.3 \\
\hline
\end{tabular}

4.1 moves per day, depending on year and region (Fig. 4). In both years in Chignecto Bay, most movement was between Hopewell and Johnson's Mills. In Minas Basin, movement was most frequently between Evangeline Beach and Porter's Point in 2013 and between Evangeline Beach and Lookoff in 2014. In Cobequid Bay in 2014, movement was most frequent between Fort Belcher and the Cobequid 3 tower (Table 1). Each of these common moves were among receivers that were $10 \mathrm{~km}$ or less apart (Table 1). Mean number of moves per bird per day was higher in Minas Basin than in Chignecto Bay (Wald $\mathrm{X}^{2}{ }_{1}=17.7, \mathrm{p}<0.0001$ ), and higher in 2014 than 2013 (Wald $\mathrm{X}_{1}{ }_{1}=56.8, \mathrm{p}<0.0001$; Fig. 4). We found no evidence that number of moves per day changed over an individual's stopover period in either 2013 (Wald $\mathrm{X}_{1}^{2}=$ $0.26, p=0.61$ ) or 2014 (Wald $X_{1}^{2}=0.55, p=0.46$; Fig. 5). Model parameters are presented in Appendix 4.

\section{Interannual regional fidelity}

Between 2013 and 2016, we resighted a total of 504 individuals returning to Chignecto Bay or Minas Basin in the Bay of Fundy. Of these birds, 495 were flagged in the Bay of Fundy between 2012 and 2014, representing $16 \%$ of the total number flagged between 2012 and 2014. The remaining nine individuals were birds that were flagged elsewhere but seen for at least two years in the Bay of Fundy. Across all years, $97 \%$ of the resighted birds returned to their original region in all subsequent years in which they were observed (Table 2). Of the 13 birds that switched regions between years, 2 moved from Chignecto Bay to Minas Basin, 9 from Minas Basin to Chignecto Bay, and 1 from Cobequid Bay to each of Chignecto Bay and Minas Basin. Those birds were all only seen in two years (banding year plus one subsequent year). We observed 95 birds in 3 or more years, and none of them switched regions. Finally, we resighted 20 radio-tracked birds in a subsequent year. Of those, only one switched regions.

Fig. 4. Boxplots of movement frequency (moves per day) based on tracking via the stationary receiver array for birds tagged in the three regions of the Bay of Fundy over both years of the study. Boxes span the interquartile range (25th and 75 th percentiles), the midline represents the median, and the whiskers represent the \pm 1.5 interquartile range. Outliers are plotted as points beyond the whiskers. Results of statistical tests are provided in the text.

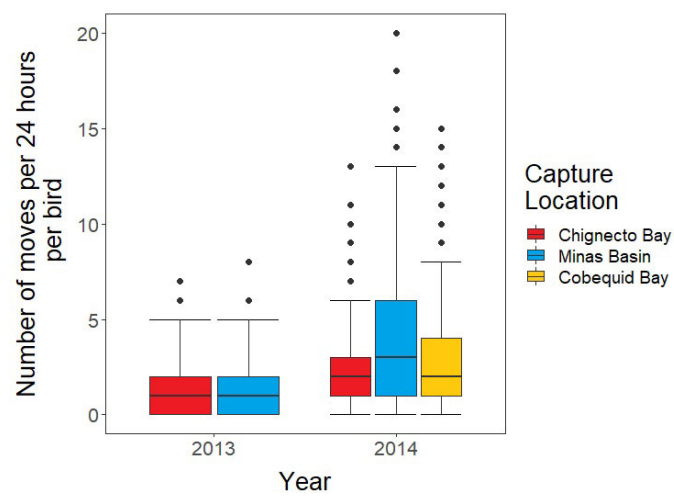


Fig. 5. Plot of number of moves per 24 hours detected on the stationary receiver array versus days after tagging for each bird tagged in (a) 2013 and (b) 2014. Region of the bay is indicated by color, and lines indicate the slope of the relationship. Individual points are offset. Results of statistical tests are provided in the text.

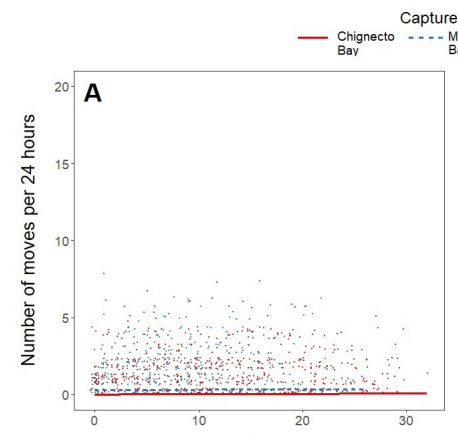

Days after tagging
Capture location
Basin
Mans
Bay

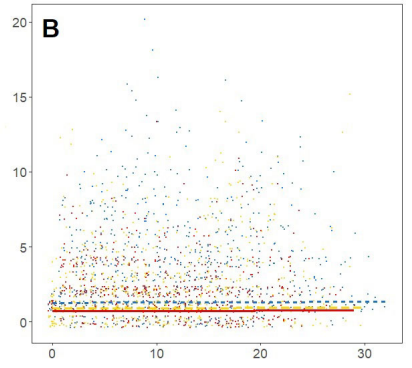

Days after tagging
Table 2. Annual resights of flagged individuals in the Bay of Fundy, indicating whether an individual returned to its original bay (Returned - R) or not (Switched - S).

\begin{tabular}{lcccccccccc}
\hline \hline $\begin{array}{l}\text { Year banded or first } \\
\text { sighted }^{\dagger}\end{array}$ & \multicolumn{10}{c}{ Year first resighted } \\
\cline { 2 - 11 } & 2013 & 2014 & 2015 & 2016 & \multicolumn{2}{c}{ Total } \\
\hline & $\mathrm{R}$ & $\mathrm{S}$ & $\mathrm{R}$ & $\mathrm{S}$ & $\mathrm{R}$ & $\mathrm{S}$ & $\mathrm{R}$ & $\mathrm{S}$ & $\mathrm{R}$ & $\mathrm{S}$ \\
2012 & 24 & 0 & 17 & 2 & 33 & 1 & 18 & 1 & 92 & 4 \\
2013 & & & 47 & 0 & 85 & 2 & 33 & 0 & 165 & 2 \\
2014 & & & & & 150 & 2 & 82 & 5 & 232 & 7 \\
2015 & 24 & 0 & 64 & 2 & 268 & 5 & 135 & 6 & 491 & 13 \\
Grand Total & & & & & & & 2 & 0 & 2 & 0 \\
\hline
\end{tabular}

${ }^{\dagger}$ Nine individuals banded in other locations were resighted over multiple years in the Bay of Fundy.

We assigned their band year as the initial year they were sighted.

\section{DISCUSSION}

\section{Local movements}

Site choice at a migratory staging area is based on several factors, including prey availability (Hicklin and Smith 1984, GossCustard et al. 1991, Hamilton et al. 2003, Sprague et al. 2008), site safety (real and/or perceived; e.g., Sitters et al. 2001, Sprague et al. 2008), fuel load (van Gils and Piersma 1999), and physical features of the environment (Danufsky and Colwell 2003). Studies of shorebird habitat use during staging have found a range of strategies, with some species remaining highly faithful to specific beaches and wetlands (Farmer and Parent 1997, Butler et al. 2002), whereas others range more widely across staging areas (van Gils and Piersma 1999, Colwell et al. 2003). This wide variety of staging behavior may be influenced by numerous factors including interspecific differences, variation between spring and fall migrations, and the structure and connectivity of the staging area itself (Farmer and Parent 1997).
Within each of the three regions of the Bay of Fundy, roosts and mudflats are separated by only shoreline and water, both of which are easily crossed by shorebirds, making travel between sites relatively easy. Therefore, it is not surprising that individual Semipalmated Sandpipers used multiple foraging and roost sites on a daily basis. Most common movement was between locations that were monitored by receivers $3-10 \mathrm{~km}$ apart. Sprague et al. (2008) reported similar levels of daily movement, though noted variation between years and locations. Extensive flight during migratory stopover is energetically expensive and can reduce fattening rates (Mann et al. 2017). Thus, from an energetic standpoint, focusing on short movements to avoid disturbance and seek foraging opportunities is likely an adaptive strategy.

We found that Semipalmated Sandpipers exhibited more movement in Minas Basin than Chignecto Bay, and somewhat more movement in 2014 than 2013. The increase in the second year of the study may be because we had more tracking towers in that year, but the difference among regions is notable. Roost sites in Minas Basin are generally more disturbed; there is substantial human activity on beaches. By contrast, important roost sites in Chignecto Bay (e.g., Johnson's Mills and Mary's Point) are protected from human disturbance. Human activities are well known to disturb shorebirds (e.g., Pfister et al. 1992, Koch and Paton 2014), and it is possible that increased movement may be related to this.

All sandpipers from Chignecto Bay, which were successfully tracked during our study, were detected at a minimum of two roosting/foraging sites, and most moved among them daily. This contrasts with Hicklin's (1987) study in which he found that only $14 \%$ of birds color marked at Johnson's Mills, the same Chignecto Bay site that we used, were detected at other sites. Possible explanations for this apparent shift include more complete detections from the use of radio-tracking in our study versus resighting in Hicklin's (1987) paper, more variable prey resources, and increased predation following the recovery of Peregrine Falcons (Falco peregrinus; Dekker et al. 2011). Overall, the flexibility in individual site use exhibited by Semipalmated Sandpipers within each region of the Bay of Fundy suggests that they are well adapted to deal with fluctuations in site suitability, such as a year of low prey density at a particular mudflat, or variable predation threats.

We found no evidence that birds adjusted their frequency of movement as they progressed through their stopover time in the region. If birds are sampling the environment to identify good food resources, one might expect more activity early in the stopover. Similarly, given that Semipalmated Sandpipers typically double their weight during their stopover, reduced movement also might be expected later in the stopover when body mass is higher and thus movement costlier (sensu Witter and Cuthill 1993). Sprague et al. (2008) found that Semipalmated Sandpipers' preference for relatively safer sites increased with time in the region and speculated that this was because ability to escape a predator quickly declined as weight increased. However, they too continued to see movement throughout the stopover. We speculate that given the relatively small scale of movements we observed within regions of the Bay of Fundy, costs of frequent local movement were outweighed by advantages of moving, perhaps in response to predators (Dekker et al. 2011) or other 
disturbances. Given the high frequency of movements we observed, to ensure efficient access to foraging habitat (sensu Dias et al. 2006) our results support the need for maintenance of a range of relatively closely connected foraging and roosting sites within each region of the bay.

\section{Intra- and interannual regional fidelity}

Although there was considerable local movement of individuals within each region, our tracking and resighting data suggest that there was very little movement between regions. Our results are consistent with Sprague et al. (2008), who found no movement of individuals between Chignecto Bay and the Minas Basin (although Cobequid Bay was not included in that study and the tracking conducted was much more limited). Further, Holberton et al. (2019) found the Semipalmated Sandpipers tagged and tracked in eastern Maine, contiguous with the outer Bay of Fundy, also used a restricted set of local sites and did not transfer to more southern areas, which were used by a different population of birds. Studies of intra-annual regional fidelity in shorebirds during migration are limited, though a similar result was also noted in Red Knots (Calidris canutus roselaari) during spring migration on the Pacific coast (Buchanan et al. 2012).

We also saw very high interannual regional fidelity, with the overwhelming majority ( $97 \%$ ) of flagged sandpipers detected in subsequent years returning to the same region where they were originally banded or observed (for those banded outside the Bay of Fundy). Because most resighted birds were seen in only two years, it is possible that this is an upper estimate of regional fidelity. If the switching rate is 3\% per year, one might expect $3 \%$ more to switch in each subsequent year, meaning that lifetime regional fidelity would be lower. However, we saw 95 birds in at least 3 years, and none of those birds switched regions in any of the years, meaning regional fidelity was actually higher across 3 years than 2. Given these data, we suggest that our observed level of regional fidelity is not a serious overestimate. Subsequent years of data on birds that did switch regions would be helpful in determining whether switching birds do so regularly. However, with only 13 birds switching at all, and only 4 radio-tracked birds moving within a season, there was little chance of detecting these individuals in future years.

Strong interannual fidelity in shorebirds is well established on the wintering (e.g., Harrington et al. 1988, Leyrer et al. 2006) and breeding grounds (e.g., Oring and Lank 1984, Haig and Oring 1988, Handel and Gill 2000), and evidence is mounting for strong fidelity during migration as well (Smith and Houghton 1984, Dinsmore et al. 1998, Buchanan et al. 2012). Combined with the high regional fidelity observed in Semipalmated Sandpipers in the Bay of Fundy, this suggests that shorebirds in general may exhibit considerable fidelity to particular segments of stopover sites during migration. Knowledge of a region gained from previous years (e.g., distribution of prey resources and the location of suitable roost habitats) may confer benefits to those that exhibit high regional fidelity (Buchanan et al. 2012).

The fact that individual birds exhibit extremely high regional fidelity raises a question of whether individuals that use different regions of the Bay of Fundy have a different breeding origin. Semipalmated Sandpipers exhibit a cline in bill length related to breeding origin; eastern breeders have the longest bills and western breeders the shortest (Gratto-Trevor et al. 2012a). It is generally assumed that the stopover population in the Bay of Fundy consists of eastern and central breeders (Hicklin and Gratto-Trevor 2010). However, we have no evidence that breeding populations are segregating within the bay. Bills of all birds banded in our study were on average $0.14 \mathrm{~mm}$ longer in Chignecto Bay than in the Minas Basin (Bliss 2015). Although statistically significant, this difference is well within the range of calculated measurement error for bill measurements (Bliss et al. 2019). Although additional data on breeding origin, perhaps obtained based on feather isotopes from hatch year birds, are needed to draw firm conclusions, based on our data we suggest that fidelity to particular regions of the bay occurs on an individual basis and not based on breeding origin, and birds of multiple origins are present in each region of the bay. This is consistent with Harrington and Morrison's (1979) observation that flocks of migrating birds, particularly in fall, have variable bill length and therefore are probably composed of individuals from different breeding origins.

\section{Diet composition and regional variation}

It was previously thought that Semipalmated Sandpipers relied heavily on Corophium volutator to fuel their migration (Hicklin and Smith 1979). Recent studies using stable isotope analysis and molecular scatology indicate birds now have a more generalized diet, including polychaete worms and biofilm (Quinn and Hamilton 2012, Gerwing et al. 2016, Neima 2017). This shift may be partially related to changes in methodology, but availability has also changed, with substantial declines in $C$. volutator documented at several mudflats, and concurrent increases in polychaetes and other prey (see discussion in Gerwing et al. 2016). Biofilm contributed significantly to the diet during our study (Gerwing et al. 2016, Neima 2017), supporting recent evidence of widespread biofilm consumption in shorebirds (Elner et al. 2005, Kuwae et al. 2008, 2012, Jardine et al. 2015, Jimenez et al. 2015). There were some regional differences in diet during 2012-2014; biofilm was more important in Chignecto Bay and polychaetes in Minas Basin (Neima 2017). This is consistent with what has been noted in previous years (Quinn and Hamilton 2012) suggesting a persistent phenomenon, at least in the past decade. Combined with the strong regional fidelity across years we observed in Semipalmated Sandpipers, this variation in diet could have long term implications for fitness and migratory success if some prey items are of higher quality than others. A preliminary analysis of prey items within the Bay of Fundy suggests that $C$. volutator, polychaetes, and biofilm all have the necessary fatty acid composition to be considered high quality prey items, provided they are consumed in sufficient quantities (Quinn et al. 2017). However, the ability of various diets to sufficiently provision sandpipers for migration is an important avenue of future research.

\section{CONCLUSION}

Throughout the stopover period, Semipalmated Sandpipers used multiple foraging and roost sites, suggesting that they are not dependent on single sites throughout their stay in the region. They may thus have the capacity to adjust their habitat use in response to changes such as an increase in predation or a decrease in prey availability at any one site. Sprague et al. (2008) found that birds prioritized site safety over food availability. Further, sandpipers 
in this region can also alter their foraging habits to deal with variation in the prey base (MacDonald et al. 2012), suggesting a flexibility that serves them well when dealing with a variable prey and predator landscape. However, they also exhibited strong intra- and interannual fidelity to three regions of the Bay of Fundy, suggesting that there are at least three staging populations of Semipalmated Sandpipers based on these areas: Minas Basin, Cobequid Bay, and Chignecto Bay. Although we have no broadscale test of this (such as a complete habitat collapse in one region of the bay), such fidelity may reduce their ability to adapt to large scale changes affecting whole subsections of the Bay of Fundy, such as changes in hydrology, sedimentation, or sea-level rise (Galbraith et al. 2002, Danufsky and Colwell 2003, Yang et al. 2005, Peterson et al. 2006). Mann et al. (2017) found that tagged Semipalmated Sandpipers remained in Cobequid Bay when extreme high tides entirely prevented roosting, even though they could have moved to another region and found roost sites. The regional fidelity that was observed in that study, and more broadly here, supports the need for conservation on a landscape scale in the Bay of Fundy because birds may not easily relocate to a different region should the habitat within their preferred region be compromised. If diet quality varies among regions, this fidelity could also theoretically result in persistent differences in fitness. An important future avenue of research is to determine whether current quantity and quality of alternate prey items in each region of the bay allow sufficient rates of fat deposition for successful migration. Further, in identifying high regional fidelity coupled with a high rate of movement within each region, our results will help to guide local conservation efforts. Data on within-region movements reveal the most common movement patterns, and thus habitat used, by Semipalmated Sandpipers during their migratory stopover in the Bay of Fundy. We recommend that these sites be prioritized in future conservation planning, and that efforts be made to maintain a network of separate but geographically close sites in each region of the bay.

Responses to this article can be read online at: http://www.ace-eco.org/issues/responses.php/1561

\section{Acknowledgments:}

Funding support was provided by Environment and Climate Change Canada, Natural Sciences and Engineering Research Council of Canada Discovery Grant (DJH) and CGSM award (SGN), Canada Summer Jobs, New Brunswick Wildlife Trust Fund, and New Brunswick Innovation Foundation. We thank the team behind the Motus Wildlife Tracking System, especially Phil Taylor, John Brzustowski, and Stu MacKenzie for support throughout the project. Many thanks also to the landowners who allowed access to beaches and mudflats and hosted towers, including the Cape Enrage Interpretive Centre, Beaubassin Research Station, Joggins Fossil Institute, Fundy Ocean Research Center for Energy, Burntcoat Head Park, Elmsdale Landscaping, Shirley and Merv Ferguson, Peggy and Blair Hamilton, Roy Bishop, Chester and Donna Sharp, Ginny Lee, Mary Majka, and David Christie. We especially thank the staff at the Nature Conservancy of Canada Johnson's Mills Shorebird Reserve and Interpretive Centre and The Hopewell Rocks for their invaluable assistance. We appreciate field assistance from
Beth MacDonald, Abby White, Claire Mussels, Brennan Obermeyer, Jenna Black, Hilary Mann, Hannah Kienzle, Amy MacDonald, Sydney Bliss, Nicole Tweddle, Sylvain Lemieux, Lauren Jonah, Jeremy Dussault, Shaun Allain, Brittany Dixon, Kirsten Snoek, Karine Duffy, Conor McKibbon-Green, Savannah Leblanc, David Drolet, Erica Geldart, and various visiting shorebird researchers and birders who joined in our banding efforts or provided resighting data. We thank two anonymous reviewers for helpful comments that allowed us to substantially improve the paper.

\section{LITERATURE CITED}

Baker, A. J., P. M. González, T. Piersma, L. J. Niles, I. de L. S. do Nascimento, P. W. Atkinson, N. A. Clark, C. D. T. Minton, M. K. Peck, and G. Aarts. 2004. Rapid population decline in Red Knots: fitness consequences of decreased refueling rates and late arrival in Delaware Bay. Proceedings of the Royal Society B: Biological Sciences 271(1541):875-882. https://doi.org/10.1098/ rspb.2003.2663

Bates, D., M. Mächler, B. Bolker, and S. Walker. 2015. Fitting linear mixed-effects models using lme4. Journal of Statistical Software 67(1):1-48. https://doi.org/10.18637/jss.v067.i01

Bliss, S. E. 2015. Morphometrics and distribution of Semipalmated Sandpipers (Calidris pusilla) in the Upper Bay of Fundy. Bachelor of Science. Mount Allison University, Sackville, New Brunswick, Canada.

Bliss, S. E., D. J. Hamilton, C. Gratto-Trevor, and J. Paquet. 2019. Are disproportionate losses of eastern breeding Semipalmated Sandpipers (Calidris pusilla) driving declines in the upper Bay of Fundy, Canada? Wilson Journal of Ornithology 131(2):260-271. https://doi.org/10.1676/17-63

Buchanan, J. B., J. E. Lyons, L. J. Salzer, R. Carmona, N. Arce, G. J. Wiles, K. Brady, G. E. Hayes, S. M. Desimone, G. Shirato, and W. Michaelis. 2012. Among-year site fidelity of Red Knots during migration in Washington. Journal of Field Ornithology 83 (3):282-289. https://doi.org/10.1111/j.1557-9263.2012.00376.x

Butler, R. W., P. C. F. Shepherd, and M. J. F. Lemon. 2002. Site fidelity and local movements of migrating Western Sandpipers on the Fraser River Estuary. Wilson Bulletin 114(4):485-490. https://doi.org/10.1676/0043-5643(2002)114[0485:SFALMO]2.0. $\mathrm{CO} ; 2$

Colwell, M. A., T. Danufsky, N. W. Fox-Fernandez, J. E. Roth, and J. R. Conklin. 2003. Variation in shorebird use of diurnal, high-tide roosts: how consistently are roosts used? Waterbirds 26 (4):484-493. https://doi.org/10.1675/1524-4695(2003)026[0484: VISUOD]2.0.CO;2

Crewe, T. L., Z. Crysler, and P. Taylor. 2019. Motus R book: a walk through the use of $R$ for Motus automated radio-telemetry data. Bird Studies Canada, Port Rowan, Ontario, Canada. [online] URL: https://motus.org/MotusRBook/

Danufsky, T., and M. A. Colwell. 2003. Winter shorebird communities and tidal flat characteristics at Humboldt Bay, California. Condor 105(1):117-129. https://doi.org/10.1093/ condor/105.1.117

Dekker, D., I. Dekker, D. Christie, and R. Ydenberg. 2011. Do staging Semipalmated Sandpipers spend the high-tide period in 
flight over the ocean to avoid falcon attacks along shore? Waterbirds 34(2):195-201. https://doi.org/10.1675/063.034.0208

Dias, M. P., J. P. Granadeiro, M. Lecoq, C. D. Santos, and J. M. Palmeirim. 2006. Distance to high-tide roosts constrains the use of foraging areas by Dunlins: implications for the management of estuarine wetlands. Biological Conservation 131(3):446-452. https://doi.org/10.1016/j.biocon.2006.02.020

Dinsmore, S. J., J. A. Collazo, and J. R. Walters. 1998. Seasonal numbers and distribution of shorebirds on North Carolina's Outer Banks. Wilson Bulletin 110(2):171-181.

Elner, R. W., P. G. Beninger, D. L. Jackson, and T. M. Potter. 2005. Evidence of a new feeding mode in Western Sandpiper (Calidris mauri) and Dunlin (Calidris alpina) based on bill and tongue morphology and ultrastructure. Marine Biology 146 (6):1223-1234. https://doi.org/10.1007/s00227-004-1521-5

Farmer, A. H., and A. H. Parent. 1997. Effects of the landscape on shorebird movements at spring migration stopovers. Condor 99(3):698-707. https://doi.org/10.2307/1370481

Galbraith, H., D. W. DesRochers, S. Brown, and J. M. Reed. 2014. Predicting vulnerabilities of North American shorebirds to climate change. PLoS ONE 9(9):e108899. https://doi. org/10.1371/journal.pone.0108899

Galbraith, H., R. Jones, R. Park, J. Clough, S. Herrod-Julius, B. Harrington, and G. Page. 2002. Global climate change and sea level rise: potential losses of intertidal habitat for shorebirds. Waterbirds 25(2):173-183. https://doi.org/10.1675/1524-4695 (2002)025[0173:GCCASL]2.0.CO;2

Gerwing, T. G., J.-H. Kim, D. J. Hamilton, M. A. Barbeau, and J. A. Addison. 2016. Diet reconstruction using next-generation sequencing increases the known ecosystem usage by a shorebird. Auk 133(2):168-177. https://doi.org/10.1642/AUK-15-176.1

Goss-Custard, J. D., R. M. Warwick, R. Kirby, S. McGrorty, R. T. Clarke, B. Pearson, W. E. Rispin, S. E. A. Le V. Dit Durell, and R. J. Rose. 1991. Towards predicting wading bird densities from predicted prey densities in a post-barrage Severn Estuary. Journal of Applied Ecology 28(3):1004-1026. https://doi.org/10.2307/2404222

Gratto-Trevor, C., R. I. G. Morrison, D. Mizrahi, D. B. Lank, P. Hicklin, and A. L. Spaans. 2012a. Migratory connectivity of Semipalmated Sandpipers: winter distribution and migration routes of breeding populations. Waterbirds 35(1):83-95. https:// doi.org/10.1675/063.035.0109

Gratto-Trevor, C., P. A. Smith, R. I. G. Morrison, Y. Aubry, and R. Cotter. 2012b. Population trends in Semipalmated Sandpipers from migration counts. Waterbirds 35(1):96-105. https://doi. org/10.1675/063.035.0110

Haig, S. M., and L. W. Oring. 1988. Mate, site, and territory fidelity in Piping Plovers. Auk 105(2):268-277. https://doi. org/10.2307/4087489

Hamilton, D. J., M. A. Barbeau, and A. W. Diamond. 2003. Shorebirds, mud snails, and Corophium volutator in the upper Bay of Fundy, Canada: predicting bird activity on intertidal mud flats. Canadian Journal of Zoology 81(8):1358-1366. https://doi. org/10.1139/z03-130
Handel, C. M., and R. E. Gill, Jr. 2000. Mate fidelity and breeding site tenacity in a monogamous sandpiper, the Black Turnstone. Animal Behaviour 60(4):471-481. https://doi.org/10.1006/anbe.2000.1505

Harrington, B. A., J. M. Hagan, and L. E. Leddy. 1988. Site fidelity and survival differences between two groups of New World Red Knots (Calidris canutus). Auk 105(3):439-445. https://doi. org/10.1093/auk/105.3.439

Harrington, B. A., and R. I. G. Morrison. 1979. Semipalmated Sandpiper migration in North America. Pages 83-100 in F. A. Pitelka, editor. Shorebirds in marine environments. Cooper Ornithological Society, Los Angeles, California, USA.

Hicklin, P. W. 1987. The migration of shorebirds in the Bay of Fundy. Wilson Bulletin 99(4):540-570. [online] URL: https://sora. unm.edu/sites/default/files/journals/wilson/v099n04/p0540-p0570. pdf

Hicklin, P. W., and C. L. Gratto-Trevor. 2010. Semipalmated Sandpiper (Calidris pusilla) in A. Poole, editor. The Birds of North America Online. Cornell Lab of Ornithology, Ithaca, New York, USA. https://birdsna.org/Species-Account/bna/species/semsan/ introduction https://doi.org/10.2173/bna.semsan.02

Hicklin, P. W., R. G. Hounsell, and G. H. Finney. 1989. Fundy pull trap: a new method of capturing shorebirds. Journal of Field Ornithology 60(1):94-101. [online] URL: https://sora.unm.edu/ sites/default/files/journals/jfo/v060n01/p0094-p0101.pdf

Hicklin, P. W., and P. C. Smith. 1979. The diets of five species of migrant shorebirds in the Bay of Fundy. Proceedings of the Nova Scotian Institute of Science 29(4):483-488. [online] URL: https:// dalspace.library.dal.ca/bitstream/handle/10222/13964/

v29_p4_a13_Hicklin_Smith_Diets_of_five_species_of_migrant_shorebirds_Bay_of_Fundy.pdf?sequence $=1$ \&isAllowed $=\mathrm{y}$

Hicklin, P. W., and P. C. Smith. 1984. Selection of foraging sites and invertebrate prey by migrant Semipalmated Sandpipers, Calidris pusilla (Pallas), in Minas Basin, Bay of Fundy. Canadian Journal of Zoology 62(11):2201-2210. https://doi.org/10.1139/ z84-321

Holberton, R. L., P. D. Taylor, L. M. Tudor, K. M. O’Brien, G. H. Mittelhauser, and A. Breit. 2019. Automated VHF radiotelemetry revealed site-specific differences in fall migration strategies of Semipalmated Sandpipers on stopover in the Gulf of Maine. Frontiers in Ecology and Evolution 7:327. https://doi. org/10.3389/fevo.2019.00327

Hope, D. D., D. B. Lank, P. A. Smith, J. Paquet, and R. C. Ydenberg. 2020. Migrant Semipalmated Sandpipers (Calidris pusilla) have over four decades steadily shifted towards safer stopover locations. Frontiers in Ecology and Evolution 8:3. https:// doi.org/10.3389/fevo.2020.00003

Jardine, C. B., A. L. Bond, P. J. A. Davidson, R. W. Butler, and T. Kuwae. 2015. Biofilm consumption and variable diet composition of Western Sandpipers (Calidris mauri) during migratory stopover. PLoS ONE 10(4):e0124164. https://doi. org/10.1371/journal.pone.0124164

Jiménez, A., R. W. Elner, C. Favaro, K. Rickards, and R. C. Ydenberg. 2015. Intertidal biofilm distribution underpins differential tide-following behavior of two sandpiper species 
(Calidris mauri and Calidris alpina) during northward migration. Estuarine, Coastal and Shelf Science 155:8-16. https://doi. org/10.1016/j.ecss.2014.12.038

Koch, S. L., and P. W. C. Paton. 2014. Assessing anthropogenic disturbances to develop buffer zones for shorebirds using a stopover site. Journal of Wildlife Management 78(1):58-67. https:// doi.org/10.1002/jwmg.631

Kuwae, T., P. G. Beninger, P. Decottignies, K. J. Mathot, D. R. Lund, and R. W. Elner. 2008. Biofilm grazing in a higher vertebrate: the Western Sandpiper, Calidris Mauri. Ecology 89 (3):599-606. https://doi.org/10.1890/07-1442.1

Kuwae, T., E. Miyoshi, S. Hosokawa, K. Ichimi, J. Hosoya, T. Amano, T. Moriya, M. Kondoh, R. C. Ydenberg, and R. W. Elner. 2012. Variable and complex food web structures revealed by exploring missing trophic links between birds and biofilm. Ecology Letters 15(4):347-356. https://doi.org/10.1111/ j.1461-0248.2012.01744.x

Leyrer, J., B. Spaans, M. Camara, and T. Piersma. 2006. Small home ranges and high site fidelity in Red Knots (Calidris $c$. canutus) wintering on the Banc d'Arguin, Mauritania. Journal of Ornithology 147(2):376-384. https://doi.org/10.1007/s10336-005-0030-8

MacDonald, E. C., M. G. Ginn, and D. J. Hamilton. 2012. Variability in foraging behavior and implications for diet breadth among Semipalmated Sandpipers staging in the upper Bay of Fundy. Condor 114(1):135-144. https://doi.org/10.1525/cond.2012.100246

MacKinnon, C. M., J. Dulude, A. C. Kennedy, S. J. E. Surette, and P. W. Hicklin. 2008. Cliff roosting by migrant Semipalmated Sandpipers, Calidris pusilla, at Farrier's Cove, Shepody Bay, New Brunswick. Canadian Field-Naturalist 122(3):274-276. https:// doi.org/10.22621/cfn.v122i3.616

Mann, H. A. R., D. J. Hamilton, J. M. Paquet, C. L. GrattoTrevor, and S. G. Neima. 2017. Effects of extreme tidal events on Semipalmated Sandpiper (Calidris pusilla) migratory stopover in the Bay of Fundy, Canada. Waterbirds 40(1):41-49. https://doi. org/10.1675/063.040.0106

Mawhinney, K., P. W. Hicklin, and J. S. Boates. 1993. A reevaluation of the numbers of migrant Semipalmated Sandpipers, Calidris pusilla, in the Bay of Fundy during fall migration. Canadian Field-Naturalist 107(1):19-23.

Mizrahi, D. S., K. A. Peters, and P. A. Hodgetts. 2012. Energetic condition of Semipalmated and Least Sandpipers during northbound migration staging periods in Delaware Bay. Waterbirds 35(1):135-145. https://doi.org/10.1675/063.035.0113

Morrison, R. I. G., D. S. Mizrahi, R. K. Ross, O. H. Ottema, N. de Pracontal, and A. Narine. 2012. Dramatic declines of Semipalmated Sandpipers on their major wintering areas in the Guianas, Northern South America. Waterbirds 35(1):120-134. https://doi.org/10.1675/063.035.0112

Neima, S. 2017. Stopover ecology of Semipalmated Sandpipers (Calidris pusilla) during fall migration through the upper Bay of Fundy, Canada. Thesis. Mount Allison University, Sackville, New Brunswick, Canada.

O'Reilly, C. T., R. Solvason, and C. Solomon. 2003. Resolving the world's largest tides. In Proceedings of the 3rd Annual National
Science Workshop. Department of Fisheries and Oceans, St. John's, Newfoundland and Labrador, Canada.

Oring, L. W., and D. B. Lank. 1984. Breeding area fidelity, natal philopatry, and the social systems of sandpipers. Pages 125-147 in J. Burger and B. L. Olla, editors. Shorebirds: breeding behavior and populations. Springer, Boston, Massachusetts, USA. https:// doi.org/10.1007/978-1-4684-4691-3_4

Peterson, C. H., M. J. Bishop, G. A. Johnson, L. M. D’Anna, and L. M. Manning. 2006. Exploiting beach filling as an unaffordable experiment: benthic intertidal impacts propagating upwards to shorebirds. Journal of Experimental Marine Biology and Ecology 338(2):205-221. https://doi.org/10.1016/j.jembe.2006.06.021

Pfister, C., B. A. Harrington, and M. Lavine. 1992. The impact of human disturbance on shorebirds at a migration staging area. Biological Conservation 60:115-126. https://doi.org/10.1016/0006-3207 (92)91162-L

Quinn, J. T., and D. J. Hamilton. 2012. Variation in diet of Semipalmated Sandpipers (Calidris pusilla) during stopover in the upper Bay of Fundy, Canada. Canadian Journal of Zoology 90(9):1181-1190. https://doi.org/10.1139/z2012-086

Quinn, J. T., D. J. Hamilton, and C. E. Hebert. 2017. Fatty acid composition and concentration of alternative food of Semipalmated Sandpipers (Calidris pusilla) in the upper Bay of Fundy, Canada. Canadian Journal of Zoology 95(8):565-573. https://doi.org/10.1139/cjz-2016-0246

Sitters, H. P., P. M. González, T. Piersma, A. J. Baker, and D. J. Price. 2001. Day and night feeding habitat of Red Knots in Patagonia: profitability versus safety? Journal of Field Ornithology 72(1):86-95. https://doi.org/10.1648/0273-8570-72.1.86

Smith, P. A., C. L. Gratto-Trevor, B. T. Collins, S. D. Fellows, R. B. Lanctot, J. Liebezeit, B. J. McCaffery, D. Tracy, J. Rausch, S. Kendall, S. Zack, and H. R. Gates. 2012. Trends in abundance of Semipalmated Sandpipers: evidence from the Arctic. Waterbirds 35:106-119. https://doi.org/10.1675/063.035.0111

Smith, P. W., and N. T. Houghton. 1984. Fidelity of Semipalmated Plovers to a migration stopover area. Journal of Field Ornithology 55:247-249.

Sprague, A. J., D. J. Hamilton, and A. W. Diamond. 2008. Site safety and food affect movements of Semipalmated Sandpipers (Calidris pusilla) migrating through the upper Bay of Fundy. Avian Conservation and Ecology 3(2):4. https://doi.org/10.5751/ ACE-00252-030204

Sutherland, T. F., P. C. F. Shepherd, and R. W. Elner. 2000. Predation on meiofaunal and macrofaunal invertebrates by Western Sandpipers (Calidris mauri): evidence for dual foraging modes. Marine Biology 137:983-993. https://doi.org/10.1007/ s002270000406

Taylor, P. D., T. L. Crewe, S. A. Mackenzie, D. Lepage, Y. Aubry, Z. Crysler, G. Finney, C. M. Francis, C. G. Guglielmo, D. J. Hamilton, R. L. Holberton, P. H. Loring, G. W. Mitchell, D. Norris, J. Paquet, R. A. Ronconi, J. Smetzer, P. A. Smith, L. J. Welch, and B. K. Woodworth. 2017. The Motus wildlife tracking system: a collaborative research network to enhance the understanding of wildlife movement. Avian Conservation and Ecology 12(1):8. https://doi.org/10.5751/ACE-00953-120108 
van Gils, J., and T. Piersma. 1999. Day and nighttime movements of radiomarked Red Knots staging in the Wadden Sea in JulyAugust 1995. Wader Study Group Bulletin 89:36-44.

White, A. 2013. Duration of stay and movements of Semipalmated Sandpipers (Calidris pusilla) during migratory stopover in the upper Bay of Fundy. Bachelor of Science. Mount Allison University, Sackville, New Brunswick, Canada.

Witter, M. S., and I. C. Cuthill. 1993. The ecological costs of avian fat storage. Philosophical Transactions: Biological Sciences 340 (1291):73-92. https://doi.org/10.1098/rstb.1993.0050

Yang, S. L., J. Zhang, J. Zhu, J. P. Smith, S. B. Dai, A. Gao, and P. Li. 2005. Impact of dams on Yangtze River sediment supply to the sea and delta intertidal wetland response. Journal of Geophysical Research: Earth Surface 110. https://doi. org/10.1029/2004JF000271

Ydenberg, R. C., R. W. Butler, D. B. Lank, C. G. Guglielmo, M. Lemon, and N. Wolf. 2002. Trade-offs, condition dependence and stopover site selection by migrating sandpipers. Journal of Avian Biology 33(1):47-55. https://doi.org/10.1034/j.1600-048X.2002.330108. $\mathrm{x}$

Ydenberg, R. C., R. W. Butler, D. B. Lank, B. D. Smith, and J. Ireland. 2004. Western Sandpipers have altered migration tactics as Peregrine Falcon populations have recovered. Proceedings of the Royal Society of London: Biological Sciences 271(1545):1263. https://doi.org/10.1098/rspb.2004.2713 


\section{Appendix 1}

Table A1.1. Details of captures of Semipalmated Sandpipers in four areas of the Bay of Fundy.

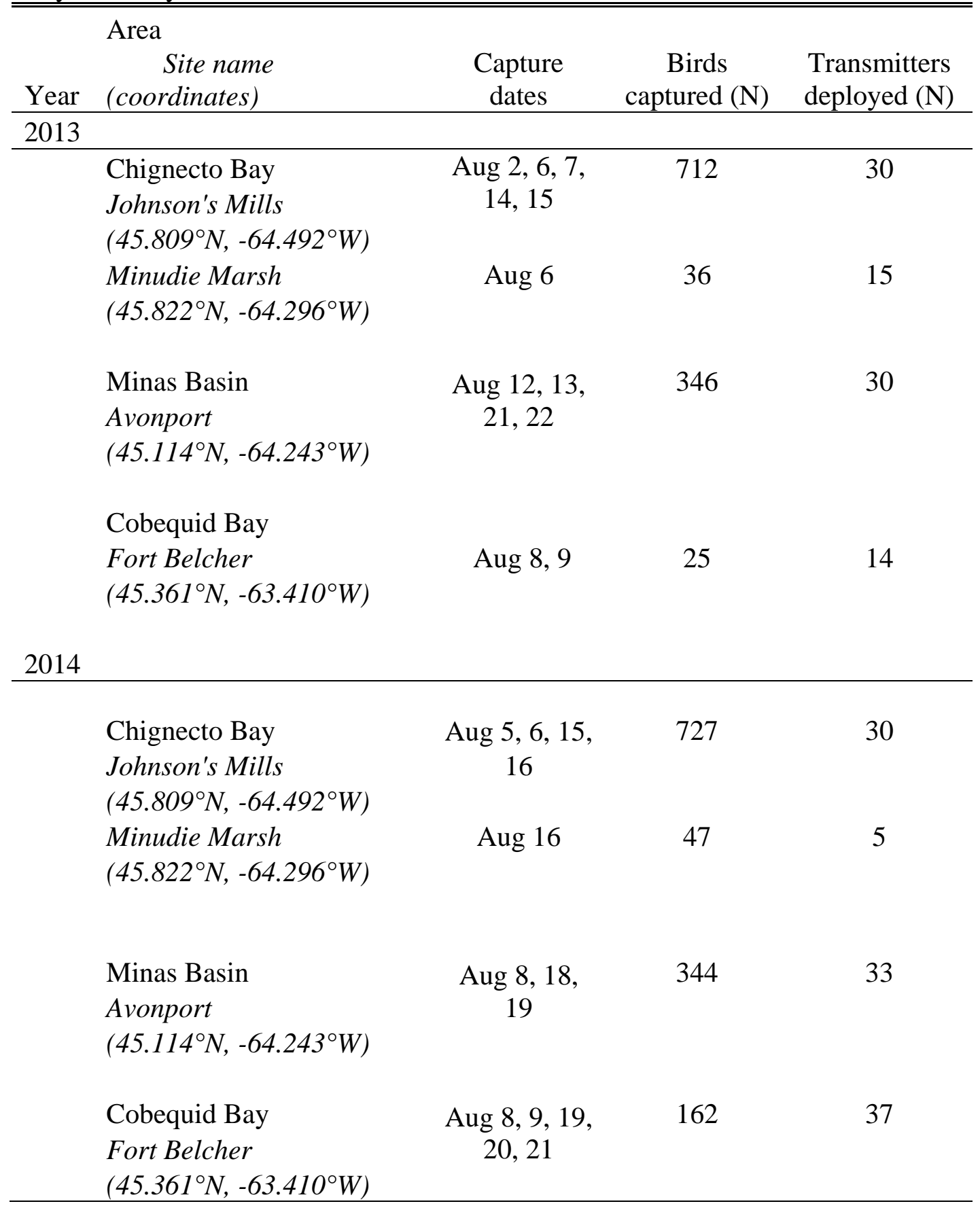




\section{Appendix 2}

Table A2.1. Locations and antenna orientations for the stationary receiver array in each year of the study.

\begin{tabular}{|c|c|c|c|c|}
\hline Area & Receiver location & Year & Coordinates & $\begin{array}{l}\text { Antenna } \\
\text { bearings }\end{array}$ \\
\hline \multirow[t]{10}{*}{ Chignecto Bay } & Johnson's Mills & 2013,2014 & $45.834^{\circ} \mathrm{N},-64.512^{\circ} \mathrm{W}$ & $210^{\circ}$ \\
\hline & $\begin{array}{l}\text { Hopewell Rocks } \\
\text { (roost) }\end{array}$ & 2013,2014 & $45.825^{\circ} \mathrm{N},-64.491^{\circ} \mathrm{W}$ & $40^{\circ}$ \\
\hline & $\begin{array}{l}\text { Hopewell Rocks } \\
\text { (flats) }\end{array}$ & 2013,2014 & $45.816^{\circ} \mathrm{N},-64.579^{\circ} \mathrm{W}$ & $220^{\circ}$ \\
\hline & Mary's Point & 2014 & $45.728^{\circ} \mathrm{N},-64.670^{\circ} \mathrm{W}$ & $175^{\circ}$ \\
\hline & Cape Enrage & 2013,2014 & $45.594^{\circ} \mathrm{N},-64.779^{\circ} \mathrm{W}$ & $90^{\circ}$ \\
\hline & Hospital Loop & 2014 & $45.867^{\circ} \mathrm{N},-64.364^{\circ} \mathrm{W}$ & $10^{\circ}, 100^{\circ}$ \\
\hline & Joggins & 2013,2014 & $45.695^{\circ} \mathrm{N},-64.450^{\circ} \mathrm{W}$ & $335^{\circ}$ \\
\hline & Mill Creek & 2014 & $45.771^{\circ} \mathrm{N},-64.377^{\circ} \mathrm{W}$ & $340^{\circ}$ \\
\hline & Beaubassin & 2013,2014 & $45.849^{\circ} \mathrm{N},-64.285^{\circ} \mathrm{W}$ & $85^{\circ}, 210^{\circ}, 260^{\circ}$ \\
\hline & Amherst Point & 2013,2014 & $45.793^{\circ} \mathrm{N},-64.284^{\circ} \mathrm{W}$ & $355^{\circ}$ \\
\hline \multirow[t]{7}{*}{ Minas Basin } & Porter's Point & 2013,2014 & $45.138^{\circ} \mathrm{N},-64.379^{\circ} \mathrm{W}$ & $145^{\circ}$ \\
\hline & Evangeline Beach & 2013,2014 & $45.139^{\circ} \mathrm{N},-64.315^{\circ} \mathrm{W}$ & $320^{\circ}$ \\
\hline & Avonport & 2013,2014 & $45.109^{\circ} \mathrm{N},-64.227^{\circ} \mathrm{W}$ & $50^{\circ}$ \\
\hline & Lookoff & 2014 & $45.207^{\circ} \mathrm{N},-64.398^{\circ} \mathrm{W}$ & $50^{\circ}, 135^{\circ}, 290^{\circ}$ \\
\hline & Lockhartville & 2014 & $45.084^{\circ} \mathrm{N},-64.215^{\circ} \mathrm{W}$ & $90^{\circ}, 225^{\circ}, 315^{\circ}$ \\
\hline & Windsor & 2013,2014 & $44.996^{\circ} \mathrm{N},-64.154^{\circ} \mathrm{W}$ & $55^{\circ}, 175^{\circ}$ \\
\hline & West Bay (FORCE) & 2013,2014 & $45.372^{\circ} \mathrm{N},-64.403^{\circ} \mathrm{W}$ & $240^{\circ}$ \\
\hline \multirow[t]{5}{*}{ Cobequid Bay } & Cobequid 1 & 2014 & $45.373^{\circ} \mathrm{N},-63.528^{\circ} \mathrm{W}$ & $190^{\circ}, 270^{\circ}$ \\
\hline & Cobequid 2 & 2014 & $45.374^{\circ} \mathrm{N},-63.480^{\circ} \mathrm{W}$ & $245^{\circ}, 315^{\circ}$ \\
\hline & Cobequid 3 & 2014 & $45.366^{\circ} \mathrm{N},-63.447^{\circ} \mathrm{W}$ & $145^{\circ}, 230^{\circ}$ \\
\hline & Fort Belcher & 2014 & $45.361^{\circ} \mathrm{N},-63.405^{\circ} \mathrm{W}$ & $180^{\circ}, 290^{\circ}$ \\
\hline & Selma & 2013 & $45.334^{\circ} \mathrm{N},-63.541^{\circ} \mathrm{W}$ & $40^{\circ}, 320^{\circ}$ \\
\hline
\end{tabular}




\section{Appendix 3}

Figure A3.1. Detailed plots depicting movement over time of individual birds tagged in Chignecto Bay, Cobequid Bay, and Minas Basin in August 2013. Regions are indicated in grey, and are separated by latitude. Color families (red, green, blue) represent birds tagged in the different regions, and color shades represent individual birds.
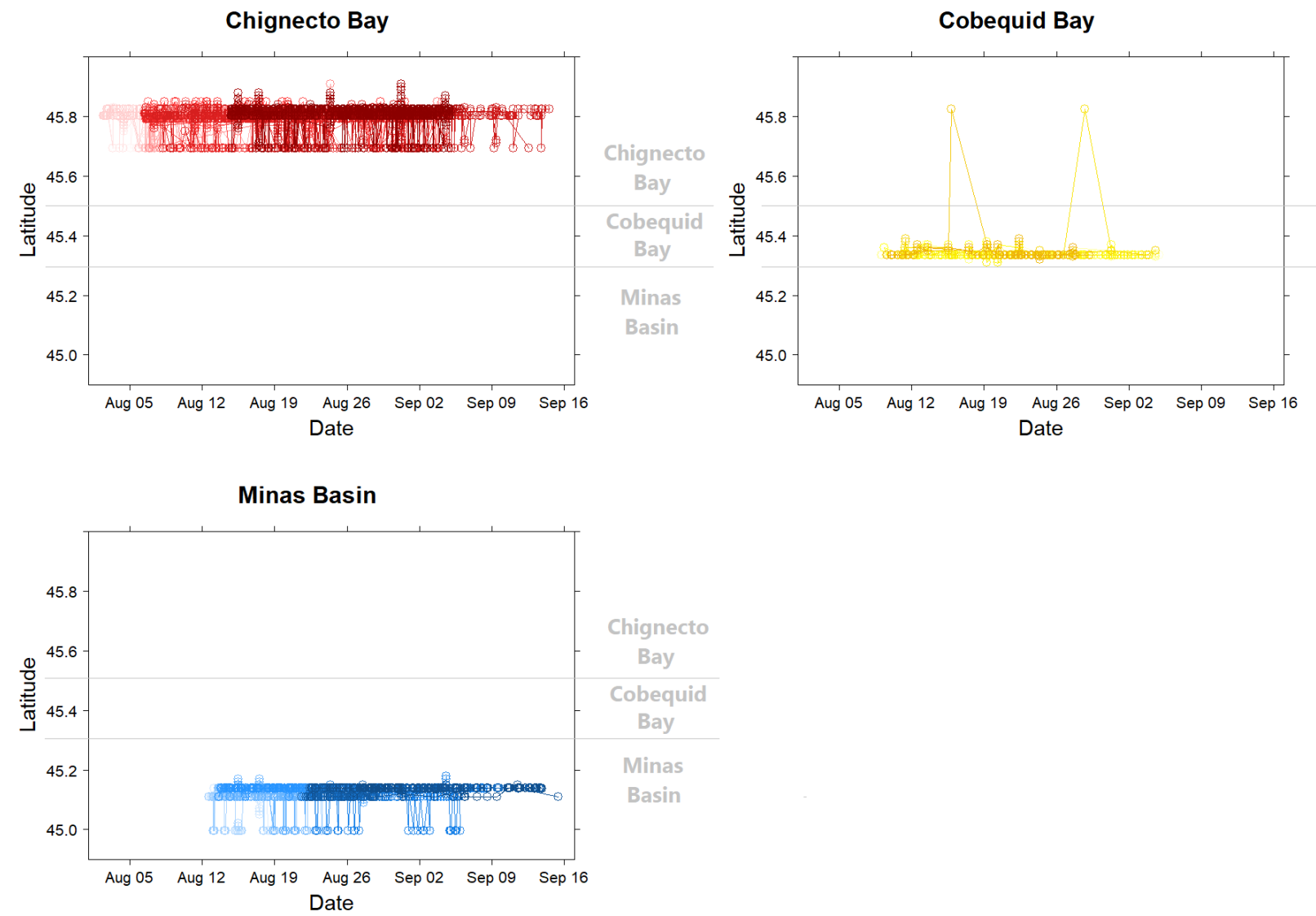
Figure A3.2. Detailed plots depicting movement over time of individual birds tagged in Chignecto Bay, Cobequid Bay, and Minas Basin in August 2014. Regions are indicated in grey, and are separated by latitude. Color families (red, green, blue) represent birds tagged in the different regions, and color shades represent individual birds.
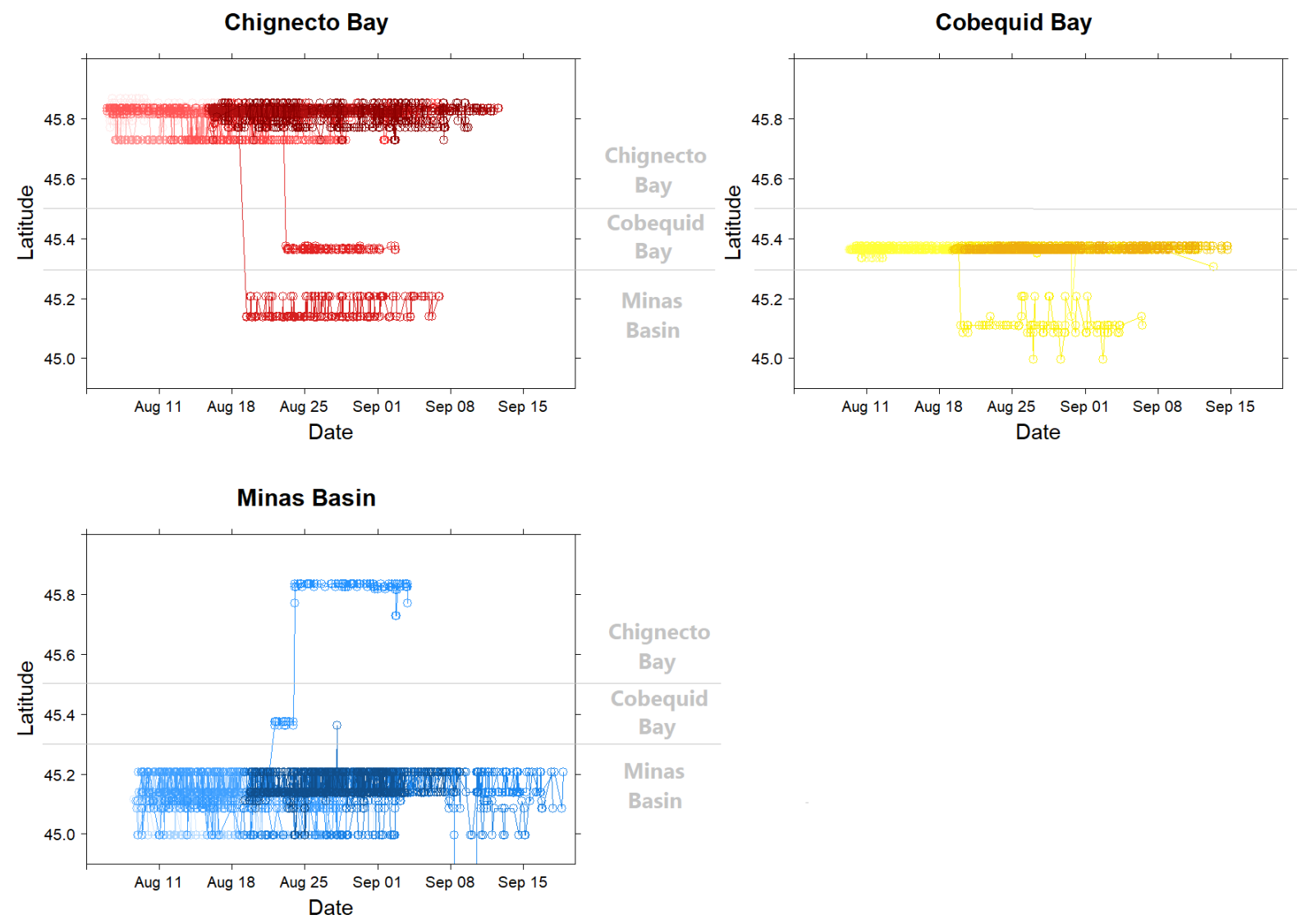


\section{Appendix 4}

Table A4.1. Parameter estimates for fixed effects in models examining rate of movement (per bird per day) relative to tagging location and days after tagging. Models were run separately for each year because Cobequid Bay was included in the analysis in 2014, but not present in 2013. $\mathrm{MB}=$ Minas Basin, $\mathrm{CH}=$ Chignecto Bay, $\mathrm{CB}=$ Cobequid Bay. Day after tagging never approached significance, so models were rerun with it removed (Table A.4.2).

\begin{tabular}{llll}
\hline \hline Model & Fixed effect & $\begin{array}{l}\text { Parameter } \\
\text { estimate }\end{array}$ & Standard error \\
\hline 2013 & $\begin{array}{l}\text { tagging location }(\mathrm{MB}-\mathrm{CH}) \\
\text { Days after tagging }\end{array}$ & 0.29 & 0.18 \\
& & 0.002 & 0.004 \\
2014 & tagging location (MB-CH) & 0.57 & 0.11 \\
& $\begin{array}{l}\text { tagging location (CB-CH) } \\
\text { Days after tagging }\end{array}$ & 0.18 & 0.11 \\
& & 0.002 & 0.003 \\
\hline
\end{tabular}

Table A.4.2. Parameter estimates for fixed effects in the model examining rate of movement (per bird per day) relative to year and tagging location. Models with and without the interaction term are presented. $\mathrm{MB}=$ Minas Basin, $\mathrm{CH}=$ Chignecto Bay.

\begin{tabular}{llll}
\hline \hline Model & Fixed effect & $\begin{array}{l}\text { Parameter } \\
\text { estimate }\end{array}$ & Standard error \\
\hline full & tagging location (MB-CH) & 0.28 & 0.15 \\
& Year (2014-2103) & 0.65 & 0.14 \\
& location x year & 0.29 & 0.21 \\
& & & \\
\multirow{2}{*}{ No interaction } & tagging location (MB-CH) & 0.43 & 0.10 \\
& Year (2014-2103) & 0.78 & 0.10 \\
\hline
\end{tabular}

